\title{
THE INFLUENCE OF SCHOOL PRINCIPAL LEADERSHIP STYLE TOWARD PRIMARY SCHOOL TEACHERS SATISFACTION
}

\author{
Safrijal \\ Doctoral Program Student of Education Management \\ State University of Medan \\ Medan, Indonesia \\ Email address: rijal.cnd@gmail.com
}

\author{
Saiful Sagala \\ Post Graduate Program of Universitas Negeri Medan \\ State University of Medan \\ Medan, Indonesia \\ Email address: syaiful_sagala@yahoo.co.id
}

\begin{abstract}
The aim of this study is to find out the influence of transformational leadership and transactional leadership toward teachers job satisfaction. The design of this research was path analysis which means the variables of this reasearch was not controled and manipulated by the researcher. The fact was revealed based on the measurement of existing phenomenon or analyzing what will happen. The sample of this research was all of the public primary school teachers in the city of Langsa which have been accredited $A$. The number of teachers were 64 . The result of study revealed that the influence of transformational leadership towards teachers job satisfaction is $45,2 \%$ and the influence of transactional leadership is $32,7 \%$. Conclusion: there is significant influence of both transformational and transactional leadership towards teachers job satisfaction.
\end{abstract}

Keywords: Leadership Style of School Principal and Teachers Job Satisfaction.

\section{INTRODUCTION}

The effort of improving the quality of education in public primary schools cannot be separated from its school principal leadership and teachers job satisfaction. The function of leadership describes how a leader directs and influences the stakeholders, how to motivate them, and how to create good cooperation and harmonious relationship among them. In term of leadership function, the leader should conceive the leadership, because the successful of the leader depends on how his leadership.

School as an institution of education is a place where the process of education is conducted. It has a complex and dynamic system. It is fact that school is not only a place for gathering teachers and students, but also it has a complex system and interrelated to each other. Therefore, the school is can be seen as an organization that requires a management. [1] Effectiveness of school depends on the efficiency of management ability, personality, and interaction with stakeholders.

The successful of education involves a lot of components. Those components are: (1) teachers, (2) students, (3) organization and (4) financing component. The four components are inter-related and very decisive to the decline and improvement of education quality. Teacher as the main component of school has significant role towrds the achievement of program which has been set by the school and towards the objective of national education. As a professional, teachers are not only required to have competnece in their expertise area, but also required to be able to explore their competence and ability, and also able to transform, develop, and spread the knowledge and technology through education as a concrete manifestation of their work performance.

[2] reveals five dimensions which can be an indicator of job satisfaction. (1) satisfaction towrds job itself. If the employee considers the job as an attractive, challenging, and giving them a chance to develop, they will show job satisfaction because of the job itself, (2) satisfaction toward salary. The salary becomes a benchmark for employees to know how far the company apprecaite their contribution to the company, (3) satisfaction on promotional occasion. Promotional occasion is given to the employees on two occasions. The first is as accomplishment produced by the employees and the second as seniority. Promotional occasion through seniority is the form of companys appreciation because of employees loyality towards the company, (4) satisfaction towards supervision. It reffers to the ability of leader to give technical support and behaviour suppor, and (5) satisfaction on co-worker. If the employees have good coworker and give positive impact to each other, the performence will be increased and they will have high level of job satisfaction. 
As it found [3], job statisfication is described as postive attitude of an individual towards his/her job. Someone with high level of statisfication shows positive attitude towards his/her job. Meanwhile, someone who is not satisfied with his/her work shows a negative attitude towards his/her work. However, [4] state that job statisfication is positive and negative attitude conducted by individuals towards their job.

Jobs satisfaction can be influenced by various aspects, one of them is leadership style of school principal. Some previous studies reveal that there is effect between leadership style and teachers job satisfaction, Fabian et. al.,[5] ; [6]; [7]; [8]; [9]; [10].

Leadership is the ability to influence and motivate others to give contribution in order to achieve the effectiveness and succsessful of organization. Leadership style is part of ledearship concept. It can be defined as a leader attitude in playing their role as the leader in their leadership. Davis and Newstorm [11] state that the total patern of leaders actions, as perceived by therir employees, is called leadership style. The style of ledearship represents the philosophy, attitude skill, and behaviour of leader. Therefore, it can be stated that the style of leadership is leaders behaviour in influencing his/her members, group, or organization in order to achieve specific achievement.

One of the new forms of leadership in organization is transformational leadership which is believed could motivate the employee in running the organization so that the organization will develop. The result of Nazim and Mahmood [12] study shows a significant relation between the style of leadership with job satisfaction. In addition, there is a relationship between both transformational and transactional leadership with job satisfaction. The study conducted by Podsakof et. al. [13] also shows transformational leadership has a significant relationship with the satisfaction of the quality of work life as a whole. Meanwhile, the result of [14] study found that the implementation of transformational leadership has good impact toward employee job satisfaction.

Transactional leadership is described as a form of leadership which provides explanation about stakeholders responsibility and their job desk along side with the rewards they can expect if the prescribed standard is reached. The result of [15] study indicate that there is relationship between transactional leadership and teachers job satisfaction.

Based on the background eludicted above, there are several factors which can influence teachers job satisfaction. Therefore, the researcher conducted a research about The Influence of School Principal Leadership Style Toward Primary School Teacher's Satisfaction in The City of Langsa.

\section{METHOD}

The design of this research was path analysis which means the variables of this reasearch was not controled and manipulated by the researcher. The fact was revealed based on the measurement of existing phenomenon or tested what will happen. The sample of this research was all of the teachers in public primary schools in the city of Langsa which have been accredited A. The number of teachers were 64 . The technique of data analysis was conducted by using SPSS version 16 .

\section{RESULT AND DISCUSSION \\ A. Description the Result of Study \\ TABLE 1. Frequency Distribution Transformational Leadership}

\begin{tabular}{|c|c|c|c|}
\hline No & Katagori & Frekwensi & Persentase \\
\hline 1 & Very High & 5 & $7,81 \%$ \\
\hline 2 & High & 26 & $40,63 \%$ \\
\hline 3 & Sufficient & 17 & $26,56 \%$ \\
\hline 4 & Low & 10 & $15,63 \%$ \\
\hline 5 & Very Low & 6 & $9,37 \%$ \\
\hline & Total & $\mathbf{6 4}$ & $\mathbf{1 0 0 \%}$ \\
\hline
\end{tabular}

The table above is the description of transformational leadership. It shows that 26 people $(40,63 \%)$ are categorized high and 17 people $(26,56 \%)$ are at the level of sufficient. In addition, $15,632 \%$ or as much as 10 people are categorized as low. Based on the data above, transformational leadership is generally well-categorized.

TABLE 2. Frequency Distribution Transactional Leadership

\begin{tabular}{|c|c|c|c|}
\hline No & Katagori & Frekwensi & Persentase \\
\hline 1 & Very High & 2 & $3,13 \%$ \\
\hline 2 & High & 16 & $25,00 \%$ \\
\hline 3 & Sufficient & 27 & $42,19 \%$ \\
\hline 4 & Low & 14 & $21,87 \%$ \\
\hline 5 & Very Low & 5 & $7,81 \%$ \\
\hline & Total & $\mathbf{6 4}$ & $\mathbf{1 0 0 \%}$ \\
\hline
\end{tabular}

The table above is the description of transactional leadership. It shows that 16 people $(25,00 \%)$ are categorized high and $27(42,19 \%)$ are at the level of sufficient. In addition, $21,87 \%$ or as much as 14 people are categorized as low. Based on the data above, transactional leadership is generally categorized as sufficient.

TABLE 3. Frequency Distribution Job Satisfaction

\begin{tabular}{|c|c|c|c|}
\hline No & Job Satisfaction & Frequency & Percentage \\
\hline 1 & Very High & 4 & $6,25 \%$ \\
\hline 2 & High & 17 & $26,56 \%$ \\
\hline 3 & Sufficient & 23 & $35,94 \%$ \\
\hline 4 & Low & 15 & $23,44 \%$ \\
\hline 5 & Very Low & 5 & $7,81 \%$ \\
\hline & Total & $\mathbf{6 4}$ & $\mathbf{1 0 0 \%}$ \\
\hline
\end{tabular}

The table above shows the data about job satisfaction. As much as 17 people $(26,56 \%)$ have high level of job satisfaction and 23 people $(35,94 \%)$ have sufficient level of job satisfaction. Meanwhile, 15 people $(23,44 \%)$ have low level of job satisfaction. The data above shows that generally, job satisfaction is categorized as sufficient. 


\section{B. The Influence of Transformational Leadership toward teachers job satisfaction}

The result of path analysis $\rho_{31}$ is known to have a path coefficient of 0,452 ; the coefficient value of this path also shows the amount of influence of transformational leadership on teacher job satisfaction that is equal to $45,2 \%$. In addition to test whether the influence of transformational leadership variables on teacher job satisfaction is significant or not, the result of teasting shows that the Sig (Significant) coloumn at Coeficietns table is $\operatorname{Sig} 0,00(0,00<0,05)$. It can be concluded that there is the influence of transformational leadership towrads teachers job satisfaction.

\section{The Influence of Transactional Leadership toward teachers job satisfaction}

The result of path analysis $\rho_{23}$ is known to have a path coefficient of 0,327 ; the coefficient value of this path also shows the amount of influence of transactional leadership on teacher job satisfaction that is equal to $32,7 \%$. In addition to test whether the influence of transactional leadership variables on teacher job satisfaction is significant or not, the result of teasting shows that the Sig (Significant) coloumn at Coeficietns table is Sig $0,00(0,00<0,05)$. It can be concluded that there is the influence of transactional leadership towrads teacher's job satisfaction.

The result of this study shows that transformational leadership is directly influnce teachers job satisfaction. Based on the result of testing path coofficent, it can be seen that the leadership of school principal is directly influnce teachers job satisfaction $(45,2 \%)$. It means that transformational leadership at school influence the mangerial and leadersip of school principal in implementing school activities and in achieving the school goals that have been established together with the board of teachers.

If the effect of transformational leadership are getting better, it will influence teachers job satisfaction. The finding of this study strengthen Hezbergs theory as qouted in [3], especially Higienes theory which states that the job satisfaction appers from the result of fulfillment of extrinsic factor such as the leader of company and supervision.

Transformational leadership is the representation of working step for school principal towards its employee. The teachers who already have job satisfaction feel that the school principles who perform their leadership always have an eye for their inspiration. The teacher also will feel that the school principle can organize the occupations properly. The result of this action towards the teacher is that the feeling of pleasure appears among the teachers. Therefore, transformational leadership is very substantial in increasing teachers job satisfaction.

The finding of this study is also [16] which states that transformational leadership can motivate the employees. As it widely known that motivation is one of the factors that can make job satisfaction appears among the employees. the study [13] shows that transformational leadership has a significant relationship with the satisfaction of the quality of work life as a whole.
The finding of this study indicates that the school principle who performs transactional leadership influence toward teachers job satisfaction directly. The leadership of school principle is directly influence teachers job satisfaction $(32,7 \%)$ based on the analysis of coofficient path. It is compatible with the theory presented [17] which states that Transactional leadership is the exchange of a value with another value. There will be a relation between leadership style and teachers job satisfaction. The function of leadership style is that physiological sense and the sense of save which are needed by the teacher can be fulfilled by transactional leadership. Besides, transactional leadership should have accurate information wbout what actually is wanted and needed by the employees. the leader also should provide constructive reciprocal reward for the teacher so that they can complete their job properly. Transactional Leadership Style that promises high rewards will make teachers tend to work better.

Transactional leadership motivates the employee to act as expected is through the reward and punishment. Transactional leadership is described as leadership which gives employees the explanation about their responsibilities and the expected reward if the standard which is previously set is achieved. The finding of this study is in line with the result of [15] study which indicates there is relation between transactional leadership and teachers' job satisfaction.

[18] state that transactional leadership lead and motivate the employees to work as expected in acheiving the target through giving the reward for their productivity.

\section{CONCLUSION}

Based on the data and the result of analysis eludicted above, it can be concluded as follows: the influence of transformational leadership toward techers job satisfaction at public primary school in the city of Langsa is equal to $45,2 \%$. Meanwhile, the percentage of teachers job satisfaction at primary school in the city of Langsa through transactional leadership is equal to $32,7 \%$.

\section{REFERENCES}

[1] Hallinger, P., and Heck, R. Reassessing the principal's role in school effectiveness: A review of empirical research. Educational Administration Quarterly. No.1:5-44. 1980.

[2] Luthans, Fred. Perilaku Organisasi. Edisi Sepuluh.Yogyakarta:Andi. 2006.

[3] Robbin, Stephen. A Judge Timothy. Perilaku Organisasi edisi 16. Jakarta: Salemba empat. 2015.

[4] Baron dan Greenberg. Behavior in Organizations.10thed. NewYork:Mc-Graw Hill. 2011.

[5] Nyenyembe, W. Fabian. Maslowski, Ralf. Nimrod, S. Beatrice. Peter, Levina. Leadership Styles and Teachers Job Satisfaction in Tanzanian Public Secondary Schools. Journal Universal of Educational Research. Vol. 4. Issue5. 2016. p. 980-988.

[6] Marshall, A. Ian. Principal Leadership Style and Teacher Satisfaction among a Sample of Secondary School Teachers in Barbados. Journal Caribbean Educational ResearchI. Vol. 2. Isusue2. 2014. p. 105-116.

[7] Griffith, J. Relation of principal transformational leadership to school staff job satisfaction, staff turnover, and school performance. Journal of Educational Administration. Vol. 42. Issue3. 2004. p. 333-356. 
[8] Bogler, R. The influence of leadership style on teacher job satisfaction. Journal Educational Administration Quarterly. Vol. 37. Issue5. 2001. p.662-683.

[9] Cerit, Y. The Effects of Servant Leader ship Behaviours of School Principals on Teachers' Job Satisfaction. Journal Educational Management Administration \& Leadership. Vol. 37. Issue50. 2009. p. 600-623.

[10] Dinham, S., \& Scott, C. A three domain model of teacher and school executive career satisfaction. Journal of Educational Administration. Vol. 36. Issue4. 2000. p. 362-378

[11] Newstrom, John W., \& Keith Davis. Organizational Behavior: Human Behavior at Work. New York: Mc. Graw-Hill Companies, Inc. 1997

[12] Fareena, Nazim. Azhar, Mahmood. Principals Transformational and Transactional Leadership Style and Job Satisfaction of College Teachers. Journal of Education and Practice. Vol.7. No.34. 2016.

[13] Podsakoff et. al. Transformational Leader Behaviors And Substitutes For Leadership Determinants Of Employee Satisfaction, Commitment, Trust, And Organizational Citizenship Behaviors. Journal of Management. No. 22. 1996. p. 259-298.

[14] Uduji, Joseph, I. (2013). Transformational leadership of a Salesforce for Higher Level of Job Satisfaction and Performance. Journal Informormation and Knowledge Management. Vol 3. Issue8. 2013. p. $81-91$. 